\title{
Vernuwing in die onderwys se invloed op navorsingstandaarde, in besonder wat die natuurwetenskappe betref
}

Wanneer oor vernuwing in die onderwys gepraat word, kan die soeklig op verskeie aspekte val.

\section{Die subsidiëring van navorsingsuitsette}

Die standaard en kwaliteit van navorsing is gekoppel aan die gehalte en voorsiening van infrastruktuur vir navorsingsaktiwiteite. Daarom is en was 'n deel van die subsidies wal universiteite ontvang het, 'n bedrag geld om "11 navorsingsinfrastruktuur te kon vestig. Die gevolg was dat universiteite in staat gestel is om navorsing op hoë vlak te kon doen.

'n Aantal jare gelede is die subsidieformule gewysig en is daar ook voorsiening gemaak om voortalan navorsingsuitsette te subsidieer.

Die doel van hierdie beleid is om universiteitspersoneel aall te moedig en te beloon vir kwaliteit navorsing van internasionale gehalte.

Die navorsingsuitsette waarna hier verwys word, is:

(1) gepubliseerde artikels in vaktydskrifte;

(2) boeke vir die vakspesialis en

(3) patente.

Die klem by hierdie navorsingsuitsette is op kwaliteit en uitstaande gehalte. Daarom is die vaktydskrifte wararna verwys word van internasionale gehalte en die redaksielede sowel as die keuringsprosedures voldoen aan die hoë vereistes wat aan sulke vaktydskrifte gestel word.

'n Artikel wat in een van die vaktydskrifte gepubliseer word en wat vir subsidiedoeleindes erken word, verdien een eenherd. Aan boeke en patente kan meer as een eenheid toegeken word.

Die beoordeling van vaktydskrifte, boeke en patente word deur vooraanstaande akademici gedoen.

Die getal eenhede wat in 1984 getel is, was 3256. Hierdie getal het in 1991 toegeneem tot 4772 . Hieruit kan duidelik gesien word watter geweldige impetus die subsidiëring van navorsingsuitsette aan die kwaliteit en kwantiteit van navorsing aan universiteite gegee het. Die stelsel is so suksesvol dat dit tans na technikons uitgebrei word.

2. Aanpassings in die subsidieformules

'n Nuwe subsidieformule vir universiteite en 'n nuwe formule vir technikons is pas aanvaar en vir die akademiese jaar 1993 geïmplementeer. Hoewel die basiese struktuur van hierdie formule ooreenstem met die vorige formule het daar klemverskuiwings plaasgevind.

In die vorige subsidieformule vir universiteite het die subsidiebedrag vir 'n student in die geestesweten- skappe teenoor 'n student in die natuurwetenskappe in die verhouding 1:1,7 gestaan. In die nuwe formule is hierdie verhouding gewysig na $1: 2,4$.

Hierdie aanpassing is gemaak na grondige navorsing wat gedoen is oor die werklike uitgawepatrone aan al die universiteite in Suid-Afrika oor 'n tienjaarperiode. In hierdie aanpassing word erkenning gegee aan die feit dat dit gemiddeld 2,4 keer meer kos om die gemiddelde student in die natuurwetenskappe op te lei. Hiermee word daar hoegenaamd geen afbreuk gedoen aan die belangrike rol van die geesteswetenskappe nie. Dit is slegs 'n poging om rekening te hou met die bekende feit dat ontwikkelende lande 'n groot behoefte aan goeie natuurwetenskaplikes het.

Hierdie vernuwing in die wyse van finansiering behoort daartoe te lei dat tersiêre inrigtings sal probeer om die groei van studentegetalle, veral in die natuurwetenskappe, te laat realiseer.

'n Verhoging van die onderrigaktiwiteite in die natuurwetenskappe sal meer personeel en nagraadse studente by navorsingsaktiwiteite betrokke maak, wat vanselfsprekend navorsingsuitsette sal stimuleer. Omdat universiteite deurgaans jaloers waak oor die kwaliteit van navorsing sal dit noodwendig lei tot 'n verdere verbetering in die kwaliteit van navorsing.

\section{Onderwysvernuwingstrategie}

Omdat talle probleme in die onderwys ervaar word, het die Komitee van Onderwysdepartementshoofde reeds in 1990 met grondige ondersoeke begin. Die resultaat hiervan is ' $n$ besprekingsdokument wat pas deur die Minister van Nasionale Opvoeding vrygestel is met die titel Onderwysvernuwingstrategie: Bestuursoplossings vir Onderwys in Suid-Afrika.

Hoewel hierdie publikasie net bedoel is om die onderwysdebat te stimuleer, word 'n verskeidenheid van baie aktuele sake aangeraak. Net enkele sake word genoem.

(1) Loopbaanonderwys behoort in die toekoms 'n groter klem in skole te kry.

(2) Daar bestaan wesenlike oorvleuelings tussen studieprogramme en studierigtings wat by tegniese kolleges, technikons en universiteite aangebied word.

(3) Aaneensluitings- of deurstromingsmoontlikhede tussen tegniese kolleges, technikons en universiteite behoort grondig ondersoek en waar moontlik, bevorder te word.

(4) Daar bestaan ' $n$ bewese behoefte aan akademiese steun- en oorbruggingsprogramme by univer- 
siteite en technikons. Die inhoud, formalat en plek van hierdie programme behoort ondersoek te word.

(5) Wat onderwysersopleiding betref, verdien die lengte en inhoud van hierdie onderrigprogramme ook besondere aandag.

(6) Volgens standpunt 9.2 van die Onderwysvernuwingstrategie (OVS) behoort wyses gevind te word waarop sentrums van uitnemendheid (veral by universiteite) gevestig kan word.

Elkeen van die genoemde sake gaan 'n wesenlike invloed op die kwaliteit en inhoud van die onderwys hê. So byvoorbeeld sal brugprogramme en aaneensluiting tussen inrigtings die poel van mensekrag wat vernuwende navorsing kan doen, aansienlik vergroot.

Daar word dus eerstens gepleit vir "n groter klem op loopbaangerigte onderwys en vir 'n nasekondêre en naskoolse onderwysstelsel met groter soepelheid. Indien hierdie weg gevolg gaan word, sal leerlinge en studente in die toekoms meer volgens hulle belangstellings en vermoëns tereg kom by onderwysinrigtings wat spesifiek hulle behoeftes sal bevredig. Eweneens beteken dit dat studente wat by universiteite studeer, primêr op basiese inhoude en grondige akademiese programme sal konsentreer. Omdat studente fyner gekeur is en daarom meer gereed is vir hierdie studies, sal onderrig en navorsing positief hierdeur beïnvloed word.

Sentra van uitnemendheid sal verder verseker dat kundigheid versterk word wat weer navorsing op spesifieke terreine sal stimuleer.

Die OVS-besprekingsdokument skep dus talle terreine waarop navorsing gedoen moet word. As navorsers en akademici hierdie baie praktiese en belangrike navorsingsterreine ondersoek en bruikbare voorstelle maak, sal navorsing per se nie net gestimuleer word nie, dit sal die onderwysstelsel in so 'n mate kan orden en verbeter dat onderrig en navorsing nog verder sal kan gedy.

\section{4. 'n Nuwe onderwysbedeling}

Suid-Afrika staan aan die vooraand van 'n totale vernuwing, ook in die onderwys. Uit die aard van die saak hang 'n nuwe onderwysbedeling nou saam met die toekomstige staatkundige model.

Een van die dinge waaroor daar 'n groot mate van eenstemmigheid is, is dat daar in die toekoms na ' $n$ streekbedeling beweeg sal word. In byna al die onderwysstelsels van die wêreld is die voorsiening van onderwys 'n aangeleentheid wat op streek-of deelstaatvlak hanteer word.

Wanneer dus gekyk word na die invloed van onderwysvernuwing op navorsingstandaarde, is die toekomstige bedeling vir universiteite, technikons en onderwyskolleges van groot belang.

Een manier om hierdie vraag dus te probeer beantwoord, is om te kyk wat in die huidige bedeling sukses verseker het en dit dan te probeer behou in enige nuwe bedeling.
* Die eerste is die outonome karakter en hantering van tersiêre inrigtings.

Hier word met outonomie bedoel die reg van tersiêre instellings om self te besluit wie onderrig gee, wat onderrig word en aan wie onderrig gegee word. Saam hiermee besluit universiteite en akademici self oor navorsingsterreine en die inhoud van navorsingsprogramme. Hierdie vryheid bied die dinamiek wat nodig is om onderrig en navorsing te laat gedy. Indien daar enigsins hiermee ingemeng word, sal dit die kwaliteit van personeel, studente en onderrigprogramme nadelig raak wat dus ook 'n invloed op alle navorsing sal hê.

Raamwerkbeheer, outonome hantering van finansies met volledige verslagdoening aan die Parlement is dus noodsaaklik in 'n nuwe bedeling.

* Om die standaard van grade en onderrigprogramme nasionaal te koördineer en sodoende minimum norme en standaarde neer te lê, is ook 'n belangrike beginsel om kwaliteit te waarborg en gelyktydig onderrig en navorsing op 'n hoë vlak te hou.

* Die Adviesraad vir Universiteite en Technikons (AUT) is 'n onafhanklike akademiese adviesliggaam wat die Minister van Onderwys adviseer oor alle sake wat universiteite en technikons raak.

Omdat hierdie liggaam se Raad uit prominente sakeleiers en akademici bestaan, geniet die AUT wye aansien en speel 'n deurslaggewende rol in die bepaling van alle beleid, ook beleid oor navorsing en navorsingsuitsette.

Naas ander belangrike eienskappe van die huidige tersiêre onderwysstelsel, is ten minste hierdie genoemde drie onontbeerlik. Met gewaarborgde outonomie en nasionale beheer oor norme en standaarde deur 'n liggaam soos die huidige AUT, sal universiteite en technikons in 'n milieu bestaan waarin onderrig en navorsing steeds kàn gedy.

Indien 'n nuwe onderwysbedeling hiermee rekening hou, behoort enige verandering in die onderwys die kwaliteit en uitnemendheid wat binne tersiêre inrigtings bestaan, nie te benadeel nie.

\section{Die invloed van onderliggende denke}

Onderwysvernuwing vind plaas binne 'n nuwe denkklimaat. In die RSA, maar ook eiders, is daar beweging

* weg van sentrale beplanning en beheer

* na die vestiging van verantwoordelikheid en aanspreeklikheid so na as moontlik aan die punt van uitvoering

* na die beklemtoning van die rol van die individu teenoor dié van die groep

* om die mededinging tussen markte te erken en te laat gedy. 
Hierdie grondverskuiwing in denkklimaat het tot gevolg dat navorsing, soos reeds gestel, in 'n vryer milieu plaasvind, maar ook dat die individu se rol, sy vryheid én verantwoordelikheid beklemtoon word. In die mate wat navorsingsuitsette die produkte van individuele denke is, is die denkklimaat verdere navorsingstimulant. Voeg hierby dat mededinging ook toenemend sal oorspoel na die navorsingsarena en sal bydra tot navorsingsondernemerskap, en dit is meteens duidelik dat die nuwe denkklimaat 'n stewige onderbou sal vorm vir verhoogde navorsingsuitsette en -standaarde.

\section{GEVOLGTREKKING}

Om dus eksplisiet te kan antwoord oor die invloed van onderwysvernuwing op navorsingstandaarde is nie eenvoudig nie en selfs nie moontlik nie.

Uit die voorgaande is dit egter duidelik dat aanpas- sings in die beleid oor navorsing navorsingstandaarde beslis positief beïnvloed het, sowel wat kwaliteit as kwantiteit betref.

Die groter klem wat op natuurwetenskappe geplaas word, sal noodwendig die natuurwetenskappe stimuleer en die land tot voordeel strek.

Die uitdaging waarvoor ons nou staan, is of die onderwysbeplanners in staat sal wees om die goeie van die verlede in nuwe toekomstige stelsels te kan behou.

Die navorsingsveld en uitdagings aan goeie navorsers het beslis geweldig uitgebrei. Die geleentheid is daar om deur kundige navorsing antwoorde op praktiese navorsingsprobleme te gee.

Of hierdie veranderings en vernuwings in die onderwys navorsingstandaarde positief gaan beïnvloed, is die opgaaf aan elke dosent en navorser in die land.

\section{J.G. PRETORIUS}

